\title{
TOWARDS AN INDIGENIZATION OF MODERNITY
}

\author{
Thierry Dufrêne'
}

\section{PARA UMA INDIGENIZAÇÃO DA MODERNIDADE \\ RESUMO}

Duas iniciativas recentes nos museus da França podem ser vistas como modos de revisitar a "nova museologia" dos anos 1970. Em 2013, Catherine Grenier curou a nova mostra permanente das coleções do Musée national d'art moderne (Centre Pompidou), intitulada Modernités plurielles, na qual ela buscou articular as chamadas artes com A maiúsculo como as artes e a cultura populares. A segunda iniciativa é a do Musée des Civilisations de l'Europe et de la Mediterranée (MuCEM), em Marselha, que acaba de lançar um programa de exposições confrontando a arte contemporânea com as artes ditas populares : a primeira, no ano passado, foi dedicada a Picasso ; a segunda, será dedicada a Jean Dubuffet. Meu artigo discute a história do que podemos chamar de "indigenização da modernidade" nos museus franceses.

PALAVRAS-CHAVE

nova museologia; arte contemporânea; artes populares

\begin{abstract}
Two recent initiatives in museums' world in France can been seen as a way to revisit the "new museology" of the 1970s. In 2013, Catherine Grenier organized the new display of the collections of the Musée national d'art moderne (Centre Pompidou) under the title Modernités plurielles, where she attempted to articulate the so-called high arts and popular arts and culture. The second initiative concerned the Musée des Civilisations de l'Europe et de la Mediterranée (MuCEM), in Marseilles, which has just launched a program of exhibitions confronting contemporary art and popular arts: the first one, last year, was dedicated to Picasso, the second (upcoming) to Jean Dubuffet. My paper addresses the history of what could be called "indigenization of modernity" in the museums in France.
\end{abstract}

\section{KEYWORDS}

new museology; contemporary art; popular arts

'Professor of History of Contemporary Art at the University Paris Nanterre. Member of the Association internationale des critiques d'art (AICA) and of the editorial board of the magazine Diogenes. Member of the "Comité d'évaluation scientifique" of the Quai Branly Museum. 
I recently participated in a colloquium dedicated to Turkish novelist Orhan Pamuk, Nobel Prize of Litterature, in Milan (January 2017). When writing his novel The Museum of Innocence, first published in Turkish language in 2008, he bought a house in Istanbul and founded a private museum, supposedly the house of Füsun, the main character of the book. The Museum of Innocence opened its doors in 2012. The first Istanbul Biennial took place in 1987. It was just 5 years after the idea of the Museum of Innocence came to Pamuk's mind, in 1982. It was almost 20 years before the Museum of Modern Art opened its doors in Istanbul, in 2004, thanks to private collectors. Orhan Pamuk wrote that museums are part of the Western civilization and not at all of the Eastern tradition. But I also claimed that "Mausoleum" was an Eastern invention: a museum or a memorial for the memory of someone. The French Revolution founded the museum for everyone, the so-called "Universal Museum", but Pamuk as a man from the Eastern tradition, criticized the notion of encyclopedic museum to prefer a more personal one, the museum of the singular, of a family. Since the 1970s, some artists such as Marcel Broodthaers (who died in 1976) had already made fun of these pretentious universal museums, derisory in their will to collect the whole of human creation. Some artists like Lusieno Indian James Luna in his performance titled The Artifact Piece (California, 1987) or more recently the Algerian-French Kader Attia at documenta 13 have shown that the history of museums is also the history of the domination of the West on the rest of the world.

The most relevant issue in Pamuk's proposal of an alternative to Western museums is that the collection of the Museum of Innocence is not a collection of artworks but a collection of things, of objects. Not a museum of works of art but a museum as a work of art. Pamuk claimed that it would be possible for everybody to display objects in his/her individual flat, in an artistic or fictional manner, as he did. In a recent exhibition in Paris at the Maison Rouge, Plus jamais seul (20I6), the artist and collector Hervé di Rosa called this specific way to do art: "Art of collections".

Harald Szeemann, who organized documenta 5 in Kassel in 1972, called Individual Mythologies, displayed two years later in 1974, belongings from his own grandfather in his own house. Born in 1944, Christian Boltanski, who is part of the so-called "art of memory", which appeared in the 1970s, presented in 1969 his first "inventaire d'objets", titled All that remains from my childhood. Considering that there were very few, Boltanski decided to use documents, photographs, objects that were similar to what he remembered of the objects from his own childhood and to present this anonymous stuff as his personal affairs. See for example Album photographique or Portraits photographiques de CB (1973). We would think they are all photographs of the artist himself, they aren't. Sometimes a beginning of a narrative appeared, with sentences each of us uses and that we could easily continue, like the very simple love story between Kemal and Füsun, and words and situations in Pamuk's novel that are intentionally trivial to be shared. Sometimes a place, a precise location is designed as in this Appartement de la rue de Vaugirard (1973): the text described the flat now empty at a specific moment in the past. Catalogs of such exhibitions looked like scientific ones, but about fakes. That same year of 1973, the Museum of Grenoble presented a show called 5 musées personnels including those of Boltanski and his wife Annette Messager.Art historian Gilbert Lascault explained in his introduction that at the time the show took place, artists were less interested in what Malraux called a "musée imaginaire", i.e. masterpieces of fine arts that could influence them, including primitive art, and many more in ethnological and folk art museums. 
That means: less by singular pieces, and more by series of objects, less by genious and more by simple people and collective behaviours and objects.

It seems clear that the artists of the 1970s have reacted against the anonymous series of conceptual art and pop art (for example the Bechers, or Warhol reproducing the same image a lot of times), as well as against the process of "accumulation" of objects by new realists. They intented to shape their dealing with objects and memory according to a dialectics between personal and common/communal, individual and society - as Boltanski did - actually pursuing a way opened by Daniel Spoerri's “musée sentimental” (1977-1989).

A few years ago, I began with some colleagues and students a research program titled The Other Arts: Territories, Itineraries, Mediations. That program is an historical enquiry and a reflection on what I call the other arts in reference to the "others of art " (in french "l'autre de l'art") of the anthropologist Daniel Fabre. For Fabre, the others of art, is what constitutes and refers to the arts that are defined or have been defined in opposition, rejected or stigmatised, compared to the "noble arts" or cultural arts (literature, poetry, painting, sculpture, music, dance, theatre, cinema), or again marginal.The others of art, is first of all a negative definition, or by default: a child's drawing, art brut, art of madmen, even prehistorical art, have had - and sometimes still have - the same difficulties getting recognition, and perhaps indeed because they do not constitute arts like the others. Yet, to talk of "other arts" as if it were a plural recount forms of alternative creation, forgotten or left aside by the sphere of Art, by art history, and which have had, perhaps because of that, a strong tendency to group together, to become hybrids, is key to invest also the field of legitimate culture. This is even more true today at a time when they are being more sharply defined, as well as being subject to a particularly innovative position in cultural heritage and the stakes of which have to be questioned.

In 2012, the marionette, intermediary object at the crossroads of practices, was a first case of study. Two days, one at the Pavilion of fair-ground art in Bercy and the other, at the Bibliothèque nationale de France (Richelieu site), were devoted to it, starting up a wider study on the question of the margins and peripheries of art. ${ }^{21}$ The programme foresaw a confrontation of a varied corpus over the next 3 years, and we did it: marionettes, puppets, wax figurines, automata, robots, fair-ground arts, circus, theatres of objects, silhouettes, caricatures, art brut, the art of the mentally handicapped, "objects of civilisation", decorative arts, crafts in the course of being qualified as aesthetic and museum material, digital arts (and games), and non-confirmed contemporary art. The colloquium Ana Gonçalves Magalhâes, Jens Baumgarten and myself organized in 2015 in Sâo Paulo in the Labex Framework was dedicated to these issues and objects. ${ }^{32}$

It has been a question of inquiring the historical blockades that explain the delay in considering certain objects worthy of integration into the sphere of art, of observing and analysing the processes of pending "artification", of elaborating a chronology of the phenomenon and stages of belonging to a cultural heritage, of determining the role of intermediaries and collectors, of questioning what is considered as "work of art".

For Renaissance scholars and artists, natural forms, ancient sculpture, works of art and the machine were all links to the same chain, a chain that

\footnotetext{
${ }^{2}$ See http://www.labex-arts-h2h.fr/-projets-.html.

${ }^{3}$ Cf. Uma história da arte alternativa: Outros Objetos, Outras Histórias - Da História Colonial ao Pós-Modernismo. (http://www.mac.usp.br/mac/conteudo/academico/publicacoes/anais/labex br fr/conteudo. html) Accessed in January 2017.
} 
united the objects exhibited in the Kunstkammer or Wunderkammer, the cabinets of curiosities fashionable between the 1540s and 1740s. But this chain was broken in the second half of the eighteenth century, as the art historian Horst Bredekamp has shown. The specialisation of museums in subjects such as history, fine arts, ethnography, science and so on, and the primacy of historical criteria have gradually made us used to exhibitions hostile to the "play" of anachronism, comparison, echo, spatial and temporal correspondence or to comparative study via hypothesis, mixture and contrast.

From the 1960s on, museums followed in the footsteps of artists — of Dada and Surrealism in particular-by staging confrontations between contemporary and archaic, "high" and popular, the everyday life and hi-tech. François Mathey (1917-1993), curator, then director of the Museum of Decorative Arts in Paris from 1953 till 1985, welcomed in 1960 Jean Dubuffet's first retrospective while the museum organized exhibitions such as L'objet (1962), the first exhibition on the comic strips in 1967, Artiste/Artisan? (1977), or still Métiers de l'art (198I). In his notes for a course at the School of the Louvre, titled «Museum and society» (1973) published in La muséologie selon Georges Henri Rivière (Dunod, on 1989), Rivière, one of the founders of "new museology", urged scholars to deal with performing arts: theatre; puppets; circus; music hall.

It was only in new multi-disciplinary museums such as the Centre Pompidou that curators were emboldened to undertake thematic exhibitions in which works remote in period and context were hung side by side. An exhibition like Musée des sacrifices. Musée de l'argent (1979) brought together contemporary artists, ancient works and non-Western arts. This continued a policy begun by Pontus Hulten at the Stockholm Moderna Museet where, in 1969, he had created the exhibition Poetry must be made by al!!/ Transform the World! which connected Oceanian art, Dada and Surrealism with the graffiti of May 1968. Jean-Hubert Martin's exhibition Magiciens de la Terre (1989) made this "serious play" with correspondences that encompassed the planet as a whole. At the time it was not sufficiently appreciated that the object of this exhibition was to place side-by-side, not only artists from different countries but works of different purposes and intentions.

More recently, two initiatives in museums' context in France can been seen as a way to revisit the "new museology" of the 1970s. In 2013, curator Catherine Grenier organized the new display of the collections of the Musée national d'art moerne (Centre Pompidou) under the title, Multiple Modernities: The presentation, wrote Grenier in her introduction of the catalog, includes a larger number of women artists, and also puts the spotlight on modern artists' interest in non-Western arts, popular art, naive art, modern life and the applied arts. The second initiative concerned the MuCEM, Museum of the civilizations of Europe and the Mediterranean Sea, in Marseille, which has just launched a program of exhibitions confronting contemporary art and popular arts: the first one, last year, was dedicated to Picasso, the second (upcoming) to Jean Dubuffet. The curator of the last one, Baptiste Brun, established in his PhD under my supervision, Jean Dubuffet - Face au paradigme primitiviste (I944-195 I) (Nanterre, juin 20I3), that Dubuffet had tried to take out the Art Brut/Naive art from "primitivism" by insisting on the "artistic operation " and its result: " the work". The practice (creative, collector, discursive) became then a critical tool. Dubuffet's work and writings aren't against modernity, but in favor of a modernity which would have integrated his "natives": the native is in this case the popular creator, the decorator of religious feasts, the decorator, the craftsman, the mechanic, the 
magician, etc. in the productions of whom the "modern" artists did not stop drawing inspiration.

Let's say that Georges-Henri Rivière, Jean Dubuffet, and nowadays Catherine Grenier and Orhan Pamuk have moved, when conceiving new museums and displays, towards the "indigenization of modernity" which Cherokee artist Jimmie Durham linked himself to childhood in 1993:

When I was a child I started making my own toys at an early age. The toys involved a very complex fantasy life, and any objects I could handle was under the constant threat of being transformed into playing a role in that private world.(...) I made my own society in which I had an important part. Something in my make-up caused me to build that society with material objects which I would change one way or another; I just had a 'bent' towards relating to objects and shapes. I suspect this is the case history of many sculptors (...). But as we grow up we are expected to translate this natural tendency to be a critical subject in the work, coupled with whatever are our natural talents, into action in the real world. (Jimmie Durham, 1993, p. 72)

\section{References}

DURHAM, Jimmie \& FISHER, Jean (eds.). A Certain Lack of Coherence : Writings on Art and Cultural Politics. Londres: Kala Press, 1993.

GRENIER, Catherine. Modernités plurielles, 1905-1970. Paris: Éditions du Centre Georges Pompidou, 2013.

PAMUK, Orhan. The Museum of Inocence. Nova York:Vintage Books, 2010. RIVIÈRE, Georges Henri. La muséologie selon Georges Henri Rivière. Cours de muséologie. Textes et témoignages. Paris: Dunod, 1989.

Recebido em março de 20 I.Aprovado em maio de 2017. 